\section{God innføring i konfliktforståelse}

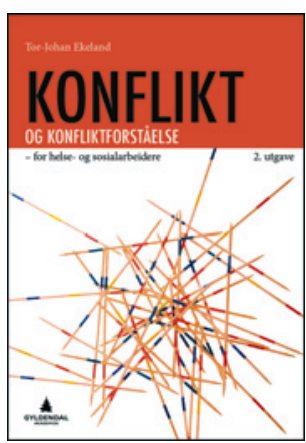

Tor-Johan Ekeland

Konflikt og konfliktforståelse

for helse- og sosialarbeidere

2. utg. 223 s, ill. Oslo: Gyldendal Akademisk, 2014. Pris NOK 389

ISBN 978-82-05-47198-6

Konflikt og konfliktforståelse for helse- og sosialarbeidere, utgitt første gang i 2004, har nå kommet i ny og revidert utgave. Forfatter og professor i sosialpsykologi Tor-Johan Ekeland ble oppfordret til å skrive en bok om emnet for mer enn 10 år siden, da konfliktforståelse ble lagt inn i rammeplaner for helse- og omsorgsfag i høyskolene.

Utgivelsen er også innrettet som en lærebok, med henvendelser til en leser ikledd rollen som student på vei ut i arbeidslivet. Dette er sikkert nyttig, og virker disiplinerende for et emne det ikke er helt enkelt å avgrense. Forfatteren er flink med begrepsavklaringer og presiseringer for å tydeliggjøre og operasjonalisere emnet, og veileder skånsomt gjennom kapitler som gradvis bygger opp vår kompetanse, særlig innen sosialpsykologi.

For en leser som ønsker rask og anvendbar kunnskap om emnet, oppleves denne ellers gode didaktiske strukturen som noe omstendelig. Det er først i de siste kapitlene at konfliktløsning og megling behandles, og da på et ganske overordnet plan. Kanskje kunne denne delen vært trukket inn tidligere, og vektet noe høyere på bekostning av de ellers gode sosialpsykologiske utlegninger og betraktninger.

Hvorfor en bok om konflikter for helse- og sosialarbeidere? Den enkle begrunnelsen er at det står på pensum i mange utdanninger. Forfatteren redegjør for hvorfor helsearbeidere spesielt bør inneha slik kunnskap; et felt preget av mange kryssende hensyn og av mange ulike interessegrupper og konstellasjoner, som i utstrakt grad må samarbeide. I en serie eksemplifiserte konflikter illustreres de mange samarbeidsarenaene og konfliktene som kan oppstå.

Litt forstyrrende er det at forfatterens betraktninger gjennomgående farges av en mistro til ansatte og en idyllisering av ledernes motiver. Ofte trer han inn i en dommerrolle i eksemplene, med mistenkeliggjøring av motivene til arbeidstakersiden eller profesjonene, som styres av egeninteresse alene. Det er pussig at de mange konfliktene mellom ansatte og ledere i de reformerte organisasjonsstrukturene i stat og kommune (e.g. foretak) ikke gis en mer dyptpløyende tolkning. Her går man glipp av en god anledning til å illustrere situasjons-, tiltaks- og målkonflikt (STM-modellen).

Heller ikke den «nordiske arbeidslivsmodellen» gis plass. Dette er etter min mening en viktig del av vår bakgrunn og våre forutsetninger både for å forebygge og for å løse konflikter. Bør med i neste utgave! Alt i alt fremstår likevel boken som en god og gjennomarbeidet innføring i emnet, og den kan anbefales for ledere med personalansvar - og tillitsvalgte.

\section{Christian Grimsgaard}

Overlege, Seksjon for overekstremitets (hånd)- og mikrokirurgi Klinikk for kirurgi og nevrofag

Oslo universitetssykehus

\section{Svakt om norsk folkehelsearbeid}

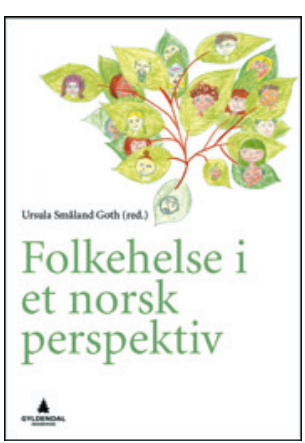

Ursula Småland Goth Folkehelse i norsk perspektiv

275 s, tab, ill. Oslo: Gyldendal Akademisk, 2014. Pris NOK 425 ISBN 978-82-05-46395-0

Denne nye boken om folkehelse er skrevet for dem som er engasjert i folkehelsearbeid og planarbeid i kommunene, men er også rettet mot helsefagstudenter på bachelor- og masternivå.

Dessverre er dette blitt en usammenhengende og ofte forvirrende fremstilling av utfordringene og metodene i norsk folkehelsearbeid. Boken består av 12 kapitler skrevet av enkeltforfattere, men vurdert og godkjent av fagfeller. Til tross for denne kvalitetssikringen finner jeg mange språklige uklarheter og merkelige formuleringer. Noen eksempler:

«Alternativt ser vi at det eksperimentelle designet, som inkluderer randomiserte kontrollerte studier, undersøker opptil flere bestemte variabler samtidig som designet ofte ikke klarer å formidle helhetsbildet» (s. 49).

«Depresjon og angst sammen med lengre tids arbeidsledighet, bidrar til økt hyppighet av psykiske plager, primært angst og depresjon» (s. 107).

«Dårlig sammensatt kosthold anses ikke lenger for å være hovedårsaken til dødelighet når det gjelder hjerte- og karsykdommer, som fortsatt er årsaken til halvparten av dødsfallene i Norge (Jenum mfl. 2007, SSB 2012). Dårlig kosthold har fortsatt stor betydning for utvikling av hjerte- og karsykdom» (s. 144).

Det er dessuten mange trykkfeil og formelle feil når det gjelder referanser. De enkelte kapitlene har svært varierende kvalitet, fra det katastrofalt dårlige (som kapittel $3 \mathrm{om}$ metodiske utfordringer, hvor forfatterne hjelpeløst forsøker å gi en oversikt over vitenskapsteori, forskningsdesign og statistiske mål på 15 sider) til de få gode (kapittel 9 om helsesøster og kapittel 12 om arbeidshelse). Et pluss er at boken omhandler migrasjonshelse og diskuterer kommunikasjon i et flerkulturelt perspektiv.

En betydelig overlapping mellom mange av kapitlene trekker ned. Det blir nærmest parodisk at den velkjente figuren med helsedeterminanter av Dahlgren og Whitehead trykkes ikke mindre enn fem ganger! For en uinnvidd leser er det også forvirrende å måtte vente til side 167 for å få en oversikt over ulike strategier i forebyggende arbeid. Innledningskapitlet («Et historisk perspektiv») kunne med fordel utelatt tre århundrer og heller bedre beskrevet hvordan folkehelsearbeidet $i$ dag er organisert, og hvilke folkehelseutfordringer Norge nå står overfor. Boken legger størst vekt på kjente atferdsfaktorer som kosthold og fysisk aktivitet, mens røyking, alkohol og andre rusmidler behandles nokså stemoderlig. De store utfordringene innen psykisk helse og helsebegrunnet frafall i skole/arbeidsliv burde også vært viet mer plass.

Alt i alt en bok som lider av for liten grundighet i det redaksjonelle arbeidet, men også av for svakt faglig nivå i mange av bidragene.

John Gunnar Mæland

Professor emeritus, Institutt for global helse og samfunnsmedisin Universitetet i Bergen

Oppgitte interessekonflikter: Anmelder er forfatter av boken Forebyggende helsearbeid - folkehelsearbeid i teori og praksis. 